\title{
THE ORGANIZATION OF CALIFORNIA PHYSICIANS' SERVICE
}

\author{
Hartley F. Peart* and Howard Hassard $\dagger$
}

California Physicians' Service is a California non-profit corporation composed of three classes of members: administrative, professional and beneficiary. Administrative members comprise a relatively small group of physicians and others ${ }^{1}$ in whom is vested administrative control of the corporation. The managers of the organization, that is, members of the Board of Trustees, are selected from and elected by the administrative members. Professional members are doctors of medicine practicing in California. ${ }^{2}$ Beneficiary members are those persons who, upon payment of monthly dues, are entitled to secure, when needed, medical and surgical services from any professional member. Hospital care is not included but may be secured from any of three non-profit hospital service associations operated throughout California.

California Physicians' Service is, therefore, a vehicle available as a means of defraying the cost of medical and surgical services on a monthly or other periodic budgeting basis." It has also been inaccurately described as a "voluntary health insurance scheme."

It is our purpose herein briefly to relate the story of the creation of California Physicians' Service, review the problems necessarily met and outline its operations. Our discussion is limited to a review of that which has occurred. We prefer to leave to others the complex task of determining whether California Physicians' Service or any similar undertaking is the answer in whole or in part to those social problems related to medicine. ${ }^{4}$

-AB., I898, University of California; LL.B., Igor, University of California, Hastings College of Law. Member of the California Bar, practicing in San Francisco. President, Bar Association of San Francisco, 1939; general counsel, California Medical Association and California Physicians' Service.

† A.B., I93I, LL.B., I934, University of California. Member of the California Bar, practicing in San Francisco. Associate counsel, California Medical Association and California Physicians' Service.

${ }^{1}$ At present there are 38 administrative members of whom 30 are doctors of medicine, one is a dentist, two are members of the clergy, one is an educator, one is a newspaper publisher, and the remaining three are business men.

2 There are approximately 5000 professional members. It is estimated that 7000 physicians are engaged. in active practice in California.

${ }^{3}$ In fact, the sole purpose set forth in the preamble to the articles of incorporation of California Physicians' Service is the general one of spreading the cost of medical care by periodic payments on the part of a large group without injuring the standards of medical service, without disruption of the proper physician-patient relation and without profit to any intervening agency.

"While it is no doubt true, to paraphrase Professor Llewellyn, that "no divinity has decreed a buggy for medicine," nevertheless, there is much to be said for extensive and complete tests of new devices before 


\section{Preliminary Considerations in Preparing a Medical Service Plan}

In November, 1938, the writers were directed by their client, the California Medical Association, to aid a special committee of the Association in the preparation of a group pre-payment medical service plan. The instructions to the committee required: only.

I. Creation of a non-profit entity so that patients' funds would be used for their benefit

2. Maintenance of the professional principle of freedom of choice of physician by each patient.

3. Avoidance of special privilege to any group or favoritism to any community and, of course, discrimination against any individual or group.

4. Creation of a type of organization that would permit administrative costs to be held to the lowest possible figure consistent with efficient operation and normal growth.

5. Maintenance of control of administration and policy in the medical profession through its representatives. ${ }^{5}$

6. Adoption of the "unit system"6 as the means of determining amounts payable to physicians and surgeons for their services.

7. Availability of the service to all California residents falling within the "restricted income groups,"7 subject only to such requirements as might be necessary to secure a reasonable spread of risks.

8. The scope of medical service included to be as broad as possible. The only exclusions contemplated were industrial injuries and illnesses, mental disorders, chronic alcoholism, drug addiction and accidents or illness arising from lawlessness. Certain limitation for pulmonary tuberculosis, pregnancy, miscarriage and childbirth were suggested.

9. District administration (with district medical directors selected so far as possible by the profession in the locality) to be maintained in order that local conditions might be recognized and local desires adhered to wherever possible.

To develop an entity meeting each of these requirements and at the same time remain within the boundaries marked out by statutes and decisions, necessarily proved to be a considerable task. So far as we were aware, there were very few

turning loose a legion of salesmen to supplant the "buggy" with a glittering, shiny "free for nothing-no down payment" stratosphere rocket ship. It is fondly hoped that California Physicians' Service is a better "buggy" and that the test pilots will pronounce it both safe and sane.

With respect to this point the special committee in a bulletin dated November 26, 1938, addressed to all members of the House of Delegates of the California Medical Association, stated: "The committec, however, recognizes the interest of the beneficiaries and the public in the funds which will be administered and intends to safeguard such funds. ..."

"The "Unit System," under the by-laws of California Physicians' Service operates as follows: At periodic intervals accumulated pooled funds are divided amongst participating physicians in accordance with the quantity of service rendered by each during the agreed-upon period and the sums thus distributed are accepted as payment in full. For example, assume that in July, 10,000 members paid a total of $\$ 17,000.00$; that after deducting for administrative costs and reserves, $\$ 14,000.00$ remains. Also, assume that there has been attributed to each type of medical and surgical service a certain number of "units," depending on the value of the service, and that physicians rendering services in July performed a total of 28,000 units of service. The unit of payment would then be 50c, and each physician would receive, as payment in full for the month of July, 5oc for each unit of service rendered by him in that month.

7 The Board of Trustees, after much discussion and inquiry, has decided upon an annual family net income of $\$ 3,000$ as the maximum income permissible for full beneficiary membership benefits. This figure is, of course, subject to future revision. "Family net income" means the total earnings of all wage earners in the family unit. Persons with incomes over $\$ 3,000$ per year are eligible to membership but may be charged an additional fee by any professional member asked to render services. 
organizations in existence operating a pooled-fund medical service plan in which the medical profession had a voice 8 and in which the "unit system" and free choice of physician were recognized and established. Neither legislation nor direct judicial precedent existed to serve as a guide. Further, our instructions did not permit devoting the time necessary for a thorough survey of service plans of any value throughout the United States.

The first problem presented was to determine what type of organization to select. Partnerships, both general and limited, ${ }^{9}$ business trusts, ${ }^{10}$ and all other unincorporated organization devices were soon eliminated because of rather apparent inadequacies. This left the corporate form and, of course, our instructions forbade the use of the ordinary private corporation organized for profit.

Thus we rapidly came to the conclusion that a non-profit corporation ${ }^{11}$ was the most feasible type of organization. Immediately, then, we were faced with two questions:

${ }^{8}$ On the Pacific Coast there are several plans in operation. The King County Medical Service Corporation, a Washington non-profit corporation, created by the King County Medical Society and operating in Seattle, is described in Brown, Private American Experimentation in Meeting Medical Needs by Voluntary Action, supra, at p. 507. The Oregon Medical Service Bureau, an Oregon corporation, operates in Portland, Oregon. It has been in existence for some time and issues a medical and hospital agreement to employed groups under which it undertakes to furnish medical and surgical services for a small monthly payment. Apparently, only physicians on the staff of the Bureau may be chosen by subscribers. Physicians are paid on a fee schedule basis. We understand, however, that recently some changes have been made in the method of operation.

The Ross-Loos group operating in Los Angeles has been highly publicized and is, perhaps, more familiar. For descriptions of the closéd-staff Ross-Loos plan, see Brown, supra at p. 509; Note (1936) 25 Calif. L. Rev. 91, 95; Ross, The Case of the Ross-Loos Clinic (1935) 25, SuRvey Graphic 300; (August 1939) 35 Readers Digest, No. 208, p. 6 I.

In 1937 the City and County of San Francisco by charter amendment (Cal. Stat, 1937, pp. 2790-2792) created a health service system. This is a compulsory "health insurance" plan for all municipal employees. A health service board was established, its members being elected by city employees. A pay-roll deduction is provided in an amount determined by the board. With the funds thus collected, the board is required to make available medical, surgical and hospital care to all municipal employees. The charter amendment forbids any "exclusive contract" and requires that the board offer free choice of physician and surgeon. A plan is now in operation under which all physicians in San Francisco are eligible to render medical services to city employees. Their compensation is based on the unit system, in accordance with a fee schedule adopted by the board. Hence, the patients and not the physicians set the value of each service.

Agricultural Workers Health and Medical Association, a California non-profit corporation, was created March 4, 1938 (Cal. Dept. of State, Corp. No. 174795), by the Farm Security Administration and the California Medical Association. It pays the cost of medical care to its members, membership being restricted to low-income farm workers. Funds are borrowed from the FSA. Any licensed doctor of medicine may render services. We are informed that no one has questioned its status under the California Insurance or Business and Professions Code.

${ }^{\circ} \mathrm{A}$ partnership was deemed unwise because of personal liability of partners for partnership debts, power of each partner to bind the partnership by contract, breach of trust or wrongful act, and automatic dissolution of partnership on the death or bankruptcy of any partner. See CAl. Crv. CoDE (Deering, 1937) $\$ \$ 2405-2409,2423-2426$. (Subsequent references to the California Codes will be to this edition.)

${ }_{10}$ Massachusetts or business trusts have many of the disadvantages of partnerships, including personal liability of the trustees for debts of the trust. Goldwater v. Oltman, 210 Cal. 408, 292 Pac. 624 (1930). In addition, they are probably taxable as corporations under the United States revenue acts. Rev. Act of 1938, \& 90I; TREAS. REG. 94; art. IOOI-2.

${ }_{12}$ In 1931 California enacted a "General Non-profit Corporation Law" comprising $\$ \$ 593$ to 605e, inclusive, of the Civil Code. $\$ 593$ provides: "A non-profit corporation may be formed by any number of persons, not less than three, for any lawful purposes, such as religious, charitable, social, educational, recreational, cemetery or for rendering services, which do not contemplate the distribution of gains, profits or dividends to the members thereof, and for which individuals lawfully may associate themselyes, ..." 
(I) Would such a corporation be unlawfully practicing medicine and surgery? and

(2) Would it be in violation of the California Insurance Code?

\section{(I) The Question as to Corporate Practice of Medicine}

Various phases of the problem of corporate practice of a learned profession have been before the California courts and it was, therefore, not impossible to ascertain the existing judicial attitude toward lay encroachments upon the professions. ${ }^{12}$ It was clear that a corporation organized for profit could not employ or in any manner control a limited group of physicians and offer their services either to the general public or to "members" of the corporation." However, the California Supreme Court, while holding that Pacific Health Corporation, Inc., ${ }^{14}$ a corporation organized for profit to its shareholders, could not lawfully select physicians for its members, took care to point out that its decision did not constitute a condemnation of non-profit corporations not offering medical services through a limited panel of physicians. The Court said:

"Our attention is called to certain data from medical and lay sources in support of the movement for group medicine and health insurance and we are told that a decision against defendant will outlaw all fraternal, religious, hospital, labor and similar benevolent organizations furnishing medical services to members. We have given careful consideration to

${ }^{12}$ Corporate practice of law, medicine or dentistry has been before the California courts quite frequently. The earliest cases were People v. Merchants Protective Corp., 189 Cal. 53r, 209 Pac. 363 (1922), and People v. Cal. Protective Corp., 76 Cal. App. 354, 244 Pac. I089 (r926), holding that a corporation could not legally furnish the services of an attorney at law. In Painless Parker v. Bd. of Dental Examiners, 216 Cal. 285, I4 P. (2d) 67 (1932), a corporation employing dentists who performed dental services for clients of the corporation was held unlawfully engaged in professional activities. In Masters v. Bd. of Dental Examiners, 15 Cal. App. (2d) 506, 5 P. (2d) 827 (1936), an order of the Board of Dental Examiners revoking a dentist's license was affirmed on the ground that the dentist had accepted employment by a corporation to render dental services to its "customers" and was, therefore, "aiding and abetting" unlawful practice of dentistry. In Pacific Employers Ins. Co. v. Carpenter, 10 Cal. App. (2d) 592, 52 P. (2d) 992 (1935), and Benj. Franklin Life Assur. Co. v. Mitchell, I4l Cal. App. (2d) 654, 58 P. (2d) 984 (1936), the refusal of the Insurance Commissioner to approve so-called "medical insurance" policy forms was upheld, the ground of refusal being that the policy forms disclosed on their face that the insurance companies contemplated employing a limited staff of physicians to render services to policy holders and that such conduct would constitute unlawful corporate practice of medicine and surgery. The latest California case is People ex rel. State Board of Medical Examiners v. Pacific Health Corp., Inc., 12 Cal. (2d) 156, 82 P. (2d) 429, II9 A.L.R. 1284 (1938). In this case, a guo warranto procecding, it appeared that Pacific Health Corporation collected monthly ducs from its "members" and in turn paid the cost of medical and surgical services rendered them by physicians it "selected." This was held unlawful corporate practice.

${ }^{13}$ In People v. Merchants Protective Corp., Masters v. Bd. of Dental Examiners, both supra note 12, and other cases, the facts disclosed employment of attorneys, dentists or physicians on a salary and use of their services for the benefit of members or customers of the corporation. All of these activitics, of course, contemplated a profit to the corporation from the professional services rendered. In the later cases, particularly Benjamin Franklin Life Assur. Co. v. Mitchell, and People v. Pacific Hcalth Corporation, Inc., both supra note 12 , the corporation did not employ professional assistants on salarics or retaincrs but merely "selected" or "appointed" persons and paid them on a predetermined fee basis. The corporations endeavored to distinguish their activities from prior cases on the ground that their designated professional staffs were independent contractors. But the form adopted was held immaterial as long as in substance a lay entity selected professional men and secured for itself all or a portion of the fruits of professional labors.

14 People v. Pacific Health Corporation, Inc., supra note 12. 
this argument and we find it wholly unconvincing. . . But it should be pointed out that the fear of applying the holding of this case to such philanthropic associations as those mentioned does not exist in the minds of the directors thereof, nor has it been suggested that the public authorities contemplate any attack on them. This illusory apprehension is expressed by defendant alone, in an attempt to bolster up its case by bringing it within the general class of associations furnishing medical or health benefits which have been tacitly approved for generations. But a most obvious and, to us, a fundamental distinction must be made between defendant and these other institutions. In nearly all of them the medical service is rendered to a limited and particular group as a result of cooperative association through membership in the fraternal or other association, or as a result of employment by some corporation which has an interest in the health of its employees. The public is not solicited to purchase the medical services of a panel of doctors; and the doctors are not employed or used to make profits for stockholders. In almost every case the institution is organized as a non-profit corporation or association. Such activities are not comparable to those of private corporations operated for profit and, since the principal evils attendant upon corporate practice of medicine spring from the conflict between the professional standards and obligations of the doctors and the profit motive of the corporation employer, it may well be concluded that the objections of policy do not apply to non-profit institutions. This view almost seems implicit in the decisions of the courts and it certainly has been the assumption of the public authorities, which have, as far as we are advised, never molested these organizations."15 (Italics added.)

This expression of public policy led us to conclude that a non-profit membership corporation which agrees to defray the costs of medical care but does not undertake to restrict its members' choice of physician and surgeon, is not, in so far as California is concerned, unlawfully engaging in the practice of medicine and surgery. ${ }^{16}$

\section{(2) The Question Whether Defraying Cost of Medical Services on Prepayment Plan is Insurance or Service}

If an organization which collects monthly or other periodic dues from its members and uses the funds thereby obtained to defray the cost to such members of medical and surgical services ${ }^{17}$ is engaged in the business of insurance, it would be necessary

${ }^{15}$ I2 Cal. (2d) at 159-I60; 82 P. (2d) at 430. Other cases, such as Group Fealth Ass'n v. Moor, 24 F. Supp. 445 (D. C. 1938), were considered but not heavily relied upon because of the thorough manner in which the California courts have covered the entire problem. For general discussions on corporate practice of medicine and whether a corporation may lawfully do so, see Notes, 73 A.L.R. I33I (r93I), ro3 A.L.R. 1238 (1936), and 119 A.L.R. 1284 (1939). See also Laufer, Ethical and Legal Restrictions on Contratt and Corporate Prattice of Medicine, supra p. 516.

${ }^{10}$ It is significant that People v. Pacific Health Corp., supra note " 12 , was a 4-3 decision, the minority expressing the opinion that any corporation could lawfully furnish to the public the services of physicians and surgeons. Query: How can the dissenting opinion be reconciled with Car. Bus. and Prof. Code \$\$2006-2008, which provide in substance that corporations and other artificial entities have no professional rights, privileges or powers? With respect to California Physicians' Service, the corporation as an entity does not "intervene" either for its own pecuniary benefit or to designate a particular physician; hence, it is submitted that no professional rights or privileges are claimed or assumed by it.

${ }^{17}$ Inasmuch as the furnishing of hospital care on a monthly payment basis by non-profit hospital service corporations is regulated by statute and is expressly subject to the jurisdiction of the California Insurance Commissioner and State Board of Health (CAL. INS. Code \$\$II49I-II5I7), it was decided to exclude hospitalization from consideration. This decision was reached with full realization of the fact that the language of $\$ 11495$ of the Insurance Code is permissive and not mandatory so that it could well be argued that the statute does not forbid one to furnish hospital care under a pooled-fund plan through a non-profit corporation which has not complied with the Insurance Code sections. 
to incorporate under appropriate insurance laws and meet all of the requirements of insurance statutes. In California, insurance companies are subjected to a $2.6 \%$ tax on gross premiums collected. ${ }^{18}$ In addition, to incorporate as an insurer would necessitate acquisition of considerable funds as statutory reserves. ${ }^{10}$ For these and other reasons ${ }^{20}$ it was the opinion of the medical profession that an insurance company would be undesirable and, if possible, should be avoided.

In principle, it is clear that to defray the cost of personal services by means of periodic payments not measured by the amount of service actually rendered in the payment period, whether such services are medical, legal or other personal efforts, does not necessarily involve insurance. The question then is whether grouping individuals together and placing periodic payments in a central fund so alters the nature of the activity that what was. previously service can be said to be insurance. Judicial decisions on this precise point are not numerous. ${ }^{21}$ One of the latest cases is Group Health Association v. Moor ${ }^{22}$ where the Court said:

"General definitions of the word 'insurance' throw little light. The statute does not include necessarily contracts 'to indemnify,' but is limited to those which provide for the 'payment' of indemnity. The word 'payment' as ordinarily used means the payment of money and I see no reason to think that the word is used in a different sense in the statute or that it is equivalent to 'indemnity'."23

It was then held that the pooling of funds to defray the cost of medical services did not constitute insurance.

Hall D'Arth v. British Provident Assn. for Health and Additional Services ${ }^{24}$ is an English case in which it was held that a non-profit association formed to reimburse

${ }^{18}$ CAL. Const. (Treadwell, 6th ed., T931) art. XIII, \$I4; Car. Poz. Code \$3664b.

${ }^{2}$ If the use of pooled funds to pay medical costs is insurance, it can only be classed as "disability" insurance. CAL. INS. CODE $§ 100$. To form a mutual disability insurer without provision for assessment of policy holders, it is necessary to obtain a "guaranty fund" of not less than \$250,000. Id. \$10562. However, a disability insurer, with provision for assessment of policy holders, in addition to the stipulated premiums, may be created upon deposit of $\$ 25,000$ with the Insurance Commissioner. Id. 510830. If the plan proposed contemplated payment of money to contract holders to reimburse for sums expended for medical and surgical services, insurance would be involved, and it would be reasonable to require at least minimum reserves. However, the use of the "unit system" removes the contingency of expenditures exceeding income and hence removes the necessity for large reserves. See note 6, supra.

${ }^{20}$ Insurance is a "business" and doctors of medicine as professional men quite naturally frowned upon classification of their services as a business enterprise. If a state bank superintendent should claim that because banks have prepared wills, all lawyers who draft wills are engaged in the banking business and are subject to his regulation, one could easily foretell the reaction of the legal profession. Further, as an insurer, California Physicians' Service would probably be unable to use the "unit system" of payment and might be required to have but one class of membership. CAL. INS. CODE \$10830 et seq.

${ }^{2 x}$ Statutory regulations are also rare. The one statute found is in Florida, defining "sickness insurance" as any contract or agreement whereby a company, corporation or association stipulates to provide for the insured either medical attention, medicine, care during disability, or money necessary for any of such purposes. Fla. Comp. Gen. Laws (1927) \$6260. See, also State ex rel. Landis v. D. C. Jones Co. 108 Fla. $61_{3}, 147$ So. 230 (1933). It is to be noted that the Florida statute includes both indemnity, i.e., money payments, and service, i.e., medical attention.

${ }_{22}{ }_{24}$ F. Supp. 445 (D. C. 1938). Since the writing of this article the Court of Appeals for the District of Columbia has affirmed the decision of the District Court that the Group Health Association is not subject to the District of Columbia insurance law. Jordan v. Group Health Ass'n, 7. U. S. LAw WeEK 261 (1939).

${ }^{23}$ Group Health Ass'n v. Moor, stipra note 22, at 446 .

$24+8$ TIMes L. R. 240,76 SOL. Jour. III (1932). 
subscribers for expenses in hospitals and for the cost of surgical operations was not an insurance company and did not write insurance. The Court expressed the opinion that the association was rendering a personal service only and that insurance does not include services.

A recent California statute authorizes the State Controller upon request to deduct from the salary of any state employee necessary dues "of any non-profit membership corporation organized under the laws of this state, for the purpose of defraying the cost of medical services" and "approved by the Director of Finance."25 The statute alșo authorizes payroll deductions for premiums on any "policy of group insurance." This statute may settle the entire problem, at least in so far as public employees are concerned, because courts do not interpret a legislative act in a manner that renders it meaningless or useless. ${ }^{26}$ To avoid such a result, legislative authorization of the activities of California Physicians' Service may be inferred. ${ }^{27}$

There are a number of cases involving personal services other than medical or surgical services in which conflicting conclusions have been reached. ${ }^{28}$ Without engaging in an exhaustive review, it is sufficient for our present purpose to state that after examination of many cases it was concluded that an organization which does not furnish services through. physicians selected by it and which, therefore, is not an entity existing between the patient and his physician, but which allows one class of its own members to render personal services to other members and receive payment therefor from a common fund, is not engaged in the insurance business but is merely a custodian of a fund. Members who render personal services clearly are not insurers and the members receiving services are merely using group resources to pay for a personal service.

As the conclusion reached was necessarily founded upon our own deductions, we submitted to the California Medical Association two types of organization, namely, a non-profit corporation with three classes of members and a mutual disability insurance company on the stipulated premium plan with provision for assessments. ${ }^{2 \theta}$ The House of Delegates of the Association, after consideration of all factors, decided to direct the creation of a non-profit corporation.

\section{Corporate Structure of California Physicians' Service}

The California Medical Association having decided to embark, for its prepayment medical service voyage, upon a non-profit membership corporation, the next step was to formulate the organization and administrative details of operation. Fortunately, California law permits great latitude in the structure of non-profit corporations. Different classes of membership with differing property, voting and other rights and privileges are permitted. ${ }^{30}$ Restrictions on transfer of membership and

${ }^{25}$ Cal. Laws, 1939, c. 895.

${ }^{28}$ County of Los Angeles v. Graves, 210 Cal. 2I, 290 Pac. 444 (1930).

${ }^{27}$ Id. at 24, 290 Pac. at 445.

${ }^{28}$ See notes, 63 A.L.R. 7TI (1929), roo A.L.R. I449 (1936), and Ir9 A.L.R. I24I (1939).

${ }^{20}$ If this type had been selected it would have been formed and operated under the California Insurance Code, \$510810-10940. See note 19, supra.

${ }^{80}$ CAI. CNv. CODE \$598(9). 
provisions governing forfeiture and termination of membership may be included in the by-laws. ${ }^{31}$ Dues or assessments may differ amongst different classes of members and one or more classes may be exempt from either dues or assessments or both. ${ }^{32}$ These and other liberal statutory provisions enabled us fully to carry out the instructions of the Association ${ }^{33}$ within the framework of a non-profit corporation.

To proceed, we shall separately review the several parts which, taken together, comprise California Physicians' Service.

Management and Policy: The management of California Physicians' Service is vested in a Board of Trustees, nine in number. Trustees are elected for three-year terms by the administrative members. Administration of the Board's policies and conduct of the corporation's affairs is placed in the hands of corporate officers. ${ }^{34}$ The power to formulate and determine policies is vested in the Board of Trustees, subject, of course, to the ultimate approval of the administrative members, who elect the trustees, and the professional members, who elect the administrative members.

Voting Control: To retain control of administration and policy in the medical profession, it was necessary to restrict the privilege of voting. At the same time, it was clear that it would be cumbersome to lodge voting power in the entire profession. Therefore, advantage was taken of the statutory provision authorizing different classes of membership.

The articles of incorporation provide for administrative members, professional members, and beneficiary members. Administrative members are limited to a maximum of 75. Administrative membership carries with it the privilege of voting for trustees, and upon all other matters submitted to the membership at large. The privilege of voting is expressly withheld from professional and beneficiary members, except that (I) professional members elect, by district, a portion of the administrative members and (2) matters of policy may be submitted to the beneficiary members for an advisory vote thereon.

It is not necessary that administrative members be doctors of medicine and nonmedical members have been elected. Administrative membership endures for a period of three years. The state has been divided into $2 x$ administrative districts and there are two administrative members from each district elected at three-year intervals, by the vote of the professional members practicing therein. Terms are staggered, however, so that all district representatives do not lose membership at once. In addition to the 42 district administrative members, the administrative members themselves may elect, by a two-thirds vote, additional administrative members to serve for three-year terms.

Through their power to elect administrative members, the professional members, who are doctors of medicine, have actual control of the corporation but at the same time direction of administration and policy is confined to a relatively small group.

${ }^{82}$ Id. $\$ 598(5)$.

${ }^{82}$ Id. \$598(10). $\quad{ }^{\text {sa }}$ See p. 566, supra.

${ }^{34}$ The offeers include a president, two vice-presidents, a secretary, a treasurer, an assistant secretary, an assistant treasurer, and a medical director. 
Free Choice of Physician: Maintenance of the professional principle of freedom of choice was, of course, a fundamental requirement. To insure as complete a freedom of choice as possible and at the same time not interfere with administrative necessities, it was decided to create a separate class of membership, that is, professional membership. All doctors of medicine licensed to practice in California are eligible to professional membership and, if by-law qualifications are met, must be admitted thereto. The only qualifications are that the applicant hold a valid license to practice medicine and surgery and maintain in force adequate professional liability insurance. Professional members as such have no right to vote (except in district elections for administrative members) and have no proprietary interest in the assets of the corporation. ${ }^{35}$ The articles expressly authorize one to hold both professional and administrative membership.

Upon becoming a professional member, a physician must agree to accept as compensation in full for all medical and surgical services rendered to beneficiary members such amounts as may become distributable under the unit system..$^{36}$ There is, however, no attempt to require each professional member to agree to perform services. ${ }^{37}$

Any beneficiary member is given the right, upon becoming entitled to receive medical or surgical services, to select as his attending physician any professional member. Inasmuch as professional membership can be acquired by any doctor of medicine as a matter of right, ${ }^{38}$ it is possible for a beneficiary member to choose any doctor of medicine in the state and, if the doctor selected actually desires to accept the member as a patient, there is no bar to his doing so, even if he is not, at the time, a professional member of California Physicians' Service. Should the doctor fail to acquire professional membership, that failure is a voluntary election on his part to reject as patients all beneficiary members.

Protection Afforded Respective Proprietary Interests of Professional Members and Beneficiary Members: The several interests considered were ( $I$ ) the interest of beneficiary members in funds contributed as dues, ${ }^{39}$ (2) the interest of professional members in the same funds as the source of compensation for medical or surgical

\footnotetext{
${ }^{85}$ The articles of incorporation do, however, provide that if the corporation is ever dissolved, professional members are entitled to be repaid the amount of any assessments paid by them if there are sufficient assets for such purpose.

${ }^{\text {so }}$ Except with respect to beneficiary members having a family net income of $\$ 3,000$ per year or more. See note 7, supra.

${ }^{87}$ Such an agreement would not be specifically enforceable. CaI. Crv. Code \$3390. Hence, if included, it could not be enforced except by expulsion from professional membership on proof of refusal to accept a beneficiary member as a patient. Such action would seriously impair the fundamental principle that all doctors of medicine may be a part of California Physicians' Service.

${ }^{88}$ Under the by-laws, the Board of Trustees cannot refuse an applicant qualified as stated above, who tenders the necessary registration fee.

${ }^{30}$ It is apparent that an enterprise that collects funds from members to defray the cost of unpredictable medical and surgical needs may, like an insurance company or a bank, be considered "clothed with a public interest," and, with respect to its administration of such funds, a "public trustee." If so, then California Physicians' Service is subject to the control of the California Attorney General. Car. Crv. Code $\$ 605 \mathrm{c}$ (supervision by Attorney. General of any non-profit corporation holding property subject to any public trust).
} 
services rendered, and (3) the interest of professional members in funds raised by direct or indirect assessment upon them.

Considering the third interest first, it was found necessary to provide organization funds, to require a registration fee for election to professional membership. It is not contemplated that the fees paid by professional members shall be returned to them. Instead, it is intended to retain the registration fee fund as "working capital." However, if dissolution should ever become necessary, the articles of incorporation provide that "after payment, satisfaction and discharge of all claims and demands against, and liabilities of the corporation, ..." there shall be distributed "to the professional members a sum equal to all assessments paid by them, and if the assets and property remaining are insufficient for a return in full to each professional member of all assessments, a pro rata distribution shall be made." Hence, the claim of professional members with respect to funds contributed by way of assessments is recognized.

To insure that dues of beneficiary members will be used solely for services which are of benefit to them, the by-laws restrict the use of corporation funds to payments of necessary administrative costs and payments to professional members for medical and surgical services rendered. No unrelated activities are permitted. In fact, no diversion of income from strictly medical matters is within the power of the corporate management. In addition, the articles require that in the event of dissolution there shall first be returned to the beneficiary members current dues, and then, after return to professional members of assessments paid, any remaining assets "shall be paid over and distributed to the beneficiary members in proportion to the amount of dues contributed by each thereof."

Undoubtedly, the most effective protection afforded beneficiary members is the unit system of payment for medical and surgical services. The unit system serves as an automatic check upon overpayment for professional services and insures that no deficit can occur. If physicians were paid for professional services upon a fee schedule expressed in terms of dollars it is conceivable that the cost of services rendered could for a considerable period exceed income, deplete the treasury and necessitate assessment of beneficiary members, large increase in dues or termination of the entire plan. These possibilities, all undesirable, are not possible under a system in which professional members accept as payment in full their pro rata share of income actually received during the preceding monthly or quarterly period.

Reserves: After payment of administration costs, current income will chiefly be used to pay professional members for services rendered. As the corporation's legal liability for the cost of future medical services is limited, under the unit system, to future income, there is no need for accumulation of large surplus funds. As the service progresses, it is, however, contemplated that the board of trustees will exercise the authority granted to it in the by-laws to set apart each month a portion of the monthly income as a reserve fund, and thus build against unforeseeable contingencies. During each monthly period current income will then be expended as follows: payment of current administration and acquisition costs, allocation of a portion of in- 
come to a reserve fund, and division of the remainder amongst professional members for professional services rendered.

Reserve funds may only' be invested in investments authorized by California law for investment of funds of savings banks. ${ }^{40}$ After a sufficient reserve is established, the by-laws require that any excess funds must be used to extend the service to beneficiary members or to reduce the cost thereof to them.

Method Adopted to Solve Problem Occasioned by Lack of Applicable Actuarial Experience: Except for the experience of the King County Medical Service Corporation, ${ }^{41}$ there is little information available to aid one to compute the amount per member per month needed to meet fully the costs of medical service in a free choice of physician plan. The problem is further complicated by the fact that the exact cost per member per month, where a fairly large group is covered, of each particular kind of medical or surgical service is likewise not precisely ascertainable.

To avoid possibility of an excess of medical expense over income available for medical costs, the unit system of payment for medical services was chosen. As previously explained, 42 the unit system involves a periodic pro rata distribution of available funds in full satisfaction of claims for services rendered during the preceding accounting period. Any reasonable time interval may be chosen as the accounting period, e.g., each calendar month or each quarter. As a consequence of the unit system, if the monthly dues prove inadequate to meet all costs, California Physicians' Service will not be in the position of an insurance company that has under-estimated the amount of premium income necessary to cover its outstanding risks. It will, of course, in such event, be necessary either to reduce the medical benefits of beneficiary membership or increase monthly dues.

In addition to adopting the unit system, California Physicians' Service has determined, at least during its early development, to restrict eligibility for beneficiary membership to persons affliated with some bona fide group of five or more. Employed groups are preferred, but any other group not created solely for the purpose of securing medical services may be acceptable. Aside from the matter of distribution of risks, one purpose of this requirement is to reduce collection costs to a minimum, thereby lessening the risk of inadequate income.

Supervision of Professional Services: It is essential in any plan involving payment for medical care to large groups from a common fund, to keep informed concerning and, if necessary, supervise the performance of professional services and hospital care in order to safeguard the fund against unnecessary expense. To meet this problem the by-laws of California Physicians' Service provide for a Medical Director and for Deputy Medical Directors in 2r.administrative districts. The Medical Director and his deputies are chosen by the Board of Trustees, but only after consultation with professional members in each district concerned. It is thus possible to select in each

\footnotetext{
${ }^{\circ}$ For authorized investments, see CaI. Civ. Code \$574, and, generally, Car. Gen. Laws act 652, \$6r.

1 See, for a deseription of the King County Service, Brown, Private American Experimentation in Meeting Medical Needs by Voluntary Action, supra at p. $5 \mathrm{II}$.

"See note 6, supra.
} 
district a Deputy Medical Director in whom the medical profession therein has confidence.

Rules and regulations have been adopted requiring each professional member to secure authorization from the Deputy Medical Director in his district before hospitalizing a beneficiary member, undertaking major surgery or any long, unusual or expensive course of treatment. One of the rules provides that professional members must report to their District Deputy Medical Director before referring beneficiary members for $\mathrm{x}$-ray examination or treatment or special clinical laboratory inyestigation. In emergency cases, the physician may, of course, proceed to hospitalize or undertake surgery at once and report later.

A determined effort has been made by the medical profession to formulate rules and regulations that will prevent unnecessary or ill-advised treatment or hospitalization yet will not operate in a manner that may unduly hamper physicians or interfere with their judgment in caring for patients. ${ }^{43}$ It is desired not to disturb the personal and confidential physician-patient relation any more than is essential for proper administration of members' funds, and acquisition of factual data for actuarial studies.

To provide actuarial statistics, case reports and other information deemed essential by the consulting actuary of California Physicians' Service are required.

Membership Certificate Forms, Contracts and Agreements: Medical Benefits Included: As there are three classes of membership, each with different duties, rights and privileges, it was necessary to provide a written evidence of membership for each class, setting forth the particular duties, rights and privileges of membership in the class concerned. Following the California non-profit corporation law, certificates of membership were adopted for issuance to each member. ${ }^{44}$ With respect to administrative membership, the certificate is brief and merely recites that California Physicians' Service is a non-profit corporation, that administrative membership is not transferable $e^{45}$ and that the person designated on the certificate is entitled to the rights and privileges of administrative membership.

In the certificate of professional membership greater detail was found desirable. Such certificates provide that during existence of membership the member has the privilege of receiving compensation from "available funds of California Physicians" Service" for medical and surgical services rendered to any beneficiary member in good standing who may need and request such services. Professional membership is not transferable voluntarily or by operation of law and the certificate so states. It is also provided that acceptance of the certificate completes an agreement by the pro-

\footnotetext{
43 The rules were prepared by leading physicians with extended experience in group medical plans.

"CAL. CIV. CODE $\$ 604$, provides: "A non-profit corporation shall not issue shares of stock, but membership in such corporation may be evidenced by certificates. . ..."

\&5 The California non-profit corporation law permits non-transferable membership and allows by-law provisions terminating membership and all of its incidents on death of the member or at a specified time. See, CAz. Civ. CODE $\$ \$ 598,602$. The articles and by-laws of California Physicians' Service prohibit the transfer of membership of any class and terminate membership on death or on the happening of certain other conditions, e.g., failure to pay dues or assessments, etc.
} 
fessional member that he will look solely to the funds of California Physicians? Service for compensation for such medical or surgical services rendered to any beneficiary member as are included within the benefits of beneficiary membership.

Shortly after California Physicians' Service was incorporated, an application for professional membership was sent to all doctors of medicine practicing in California. The application form adopted contains representations by the applicant that (I) he is legally licensed to practice medicine in California, (2) he agrees to be bound by the articles of incorporation, by-laws, schedules of compensation for professional services and their unit systems and rules and regulations of California Physicians' Service, and (3) he agrees to carry malpractice insurance in designated amounts while a professional member.

With respect to beneficiary membership, it was early decided that California Physicians' Service should have authority to issue several different service agreements having different benefits and different dues rates. It was also decided that sound development of the plan required restriction of beneficiary membership to persons affiliated in groups so that an adequate spread could be obtained and an inexpensive and convenient means of collecting monthly dues would be available.

To contract with groups, such as employee associations, labor unions, and others, it was found desirable to adopt not only individual beneficiary membership certificates but also master contract forms to cover the various arrangements necessary to be made with the group itself. In addition, to be able to offer different benefits and monthly dues, it was necessary to devise some means whereby the duties and privileges of beneficiary membership could be made flexible. Fortunately, California law authorizes non-profit corporations, through appropriate by-law provisions, to levy dues "upon all classes of membership alike, or in different amounts or proportions or upon a different basis upon different classes of membership."46 Further, "membership of one or more classes may be made exempt from either dues or assessments or both." 47

Accordingly, the by-laws provide that the Board of Trustees may create several divisions of beneficiary membership and that the dues of each division may differ. At the present time there are two divisions. Under one division, beneficiary membership includes all medical and surgical services found necessary as a consequence of illness or injury, with the following limitations:

(a) Maximum length of treatment of one year for any one illness or injury;

(b) A waiting period of twelve months for hernias, tonsilectomies, and adenoid and nasal septum operations; and

(c) A waiting period of twenty-four months for pregnancy, miscarriage or childbirth.

In addition the following are excluded:

r. All conditions existing at time of acquisition of membership;

2. Chronic alcoholism, drug addiction, mental disorders;

3. Injuries or illness for which care or treatment is provided under any workmen's compensation or employers' liability law;

“CAL. CIv. CODE \$598(10).

${ }^{87} 1 b i d$. 
4. Injuries arising out of lawlessness or intentionally self-inflicted; and

5. Dental services.

The second division of beneficiary membership presently established is identical to the first division, except that the cost of the first two ordinary visits to any professional member for any one illness or injury must be paid by the beneficiary member. Such payment is made directly to the professional member. Monthly dues are, of course, less than for membership in the first division.

Further divisions can be created from time to time if different coverages are found desirable and if particular classes of persons should be included; for example, if governmental care for indigent or low income workers should be entrusted to California Physicians' Service. ${ }^{48}$

In order to have definite and uniform arrangement with various groups acquiring beneficiary membership, master "medical service agreements" have been adopted. The agreements contemplate two parties, viz., California Physicians' Service and the agency representing prospective beneficiary members. The medical and surgical services included and those excluded or qualified are set forth in detail in the master agreement.

In those instances in which the contracting party is an employer, a clause providing for a pay roll deduction is included. If the contracting party is not an employer, a clause providing that the group shall be "responsible for" the collection of monthly dues is substituted.

In addition, the "medical service agreements" provide that: Service;

I. Hospital care is not within the benefits of membership in California Physicians'

2. Each member of the group or agency who becomes a beneficiary member of California Physicians' Service thereby agrees to be bound by its articles, by-laws and rules and regulations;

3. Beneficiary membership is not transferable voluntarily or by operation of law;

4. California Physicians' Service is not responsible for negligence or other wrongful acts on the part of its professional members;

5. The Medical Director of California Physicians' Service or any physician whom he may designate, may, pursuant to rules and regulations of California Physicians' Service "decide whether the physical condition of any member requires treatment, and, if so, what treatment";

6. Professional members are subrogated to the rights of beneficiary members in the event of an existing right to recover or recovery of the cost of medical care from any third party;

7. Beneficiary membership shall endure during the life of the agreement except that if an employee-member ceases to be affliated with the contracting group he may maintain beneficiary membership for a maximum period of six months thereafter;

8. The entire agreement may be cancelled on ninety days' notice by either party and, if cancelled, all beneficiary memberships issued thereunder likewise terminate;

9. There is a grace period for payment of beneficiary membership dues and at the expiration of the grace period all right to benefits ceases; and

${ }^{43}$ See p. 582, infra. 
10. All disputes between members, beneficiary or professional, or between a member and California Physicians' Service, must be submitted to arbitration.

Upon execution of a medical service agreement with any group or organization, each member of the group is then presented with an application for beneficiary membership. Upon completing the application, an individual certificate of beneficiary membership is issued to the new member. The master agreement is not distributed to each person in the group and, therefore, the certificate of beneficiary membership contains a full statement of the medical and surgical services excluded or qualified. In addition, the certificate has attached to it printed instructions so that each beneficiary member may know what steps to pursue in the event of illness or injury. ${ }^{49}$ In order that each beneficiary member may know whether his own physician is a professional member, a list of such members is furnished each contracting group.

Monthly Dues: At present, dues for the first division of beneficiary membership (full coverage) are $\$ 1.70$ per month. Dues for the second division (under which the member pays the cost of first two professional visits) are $\$$ r.20 per month. If the member holds a hospital contract, he pays an additional 80 cents per month which is collected at the same time as his California Physicians' Service dues, thus making total monthly payments of $\$ 2.50$ or $\$ 2.00$.

Selection of Risk and Distribution of Loss: We have previously pointed out that beneficiary membership is restricted to groups having some method available for collection of monthly dues. This, of course, eliminates individual self-selected risks who are, usually, in immediate need of medical care. Dependents are also excluded, unless they are members of a contracting group, because of unfortunate experiences elsewhere with this type of risk. ${ }^{50}$ Another check upon beneficiary membership

${ }^{\circ}$ The instructions read as follows: "IN THE EVENT OF NEED FOR MEDICAL SERVICES:

I) Secure from your employer an identification form which he will fill out.

2) You may choose any doctor who is a Professional Member of California Physicians' Service. A list of members is on file with your employer. Select your doctor as you would if you were paying him yourself. You are not restricted in any way so long as the doctor is a Professional Member of California Physicians' Service. The doctors, however, have the same freedom in selecting patients as you have in selecting doctors.

3) If your doctor determines that you need hospital care, use the hospital service contract you hold.

4) You are entitled to all necessary medical and surgical services for diagnosis and treatment, except for: [Here follows the list of the coverage cxceptions and of the service subject to a waiting period set forth on pp. 577-578, supra.]

6) As long as you remain a Beneficiary Member you are entitled to necessary medical and surgical services up to a maximum of one year for each illness or injury.

7) Before undertaking special diagnostic matters or special treatments your physician must, by the terms of his Professional Membership agreement with California Physicians' Service, secure authorization of the Medical Director.

8) In the event you leave the service of your present employer, you are entitled to service during the month for which you have paid ducs. However, by continuing to pay your dues in advance, you may maintain your Beneficiary Membership, entitled to all the benefits thereof, for a period of six months. This temporary extension of coverage may make it possible for you to maintain continuous protection if you return to your present employment or secure other employment in a group holding a contract with California Physicians' Service.

9) If the net annual income of a Beneficiary Member exceeds $\$ 3,000.00$ the attending Professional Member may, by the terms of the contract of membership, charge a fee in excess of the sum paid to him by California Physicians' Service.".

${ }^{50}$ Dependents are also self-selected risks and, hence, costly. The San Francisco Health Service System 
which is expected to enable California Physicians' Service to avoid the difficulties involved in selection of risks, is the exclusion from medical and surgical care of pre-existing conditions.

To secure a reasonable distribution of loss, California Physicians' Service has determined not to accept groups of less than ten unless all members of the group acquire beneficiary membership and to accept groups over ten only if a substantial $(40-70 \%)$ number of the group apply and secure membership.

Whether the precautions discussed are sufficient or, on the other hand, too conservative, only time and experience can prove.

Hospitalization Benefits: As previously stated, hospital care is not included within the benefits of beneficiary membership in California Physicians' Service. Several considerations led to the omission of hospitalization. First, and most important, there are, in California, three non-profit hospital service corporations, each furnishing hospital care to subscribers for a small monthly payment. ${ }^{51}$ As these organizations were founded and are now operated through the joint efforts of medical societies and the hospitals in the state, it was immediately decided to work in harmony with them and leave entirely to them the field of hospital care on a periodic payment plan. Another consideration, although not controlling, was the Insurance Code chapter authorizing non-profit hospital service corporations to submit to regulation and supervision of the Insurance Commissioner. ${ }^{52}$ While it may reasonably be contended that hospital care, like medical care, is primarily a personal service and hence not within the category of insurance, nevertheless, in view of the services offered by non-profit hospital service corporations, it was thought not necessary to rely or act upon this proposition.

Realizing that the average person who desires to budget his sickness and injury costs will want to obtain, if. possible, protection against both medical and hospital expenses, California Physicians' Service and the hospital service corporation have an arrangement under which groups may acquire at the same time and for the same period, both beneficiary membership in California Physicians' Service and hospitalization contracts. Under this arrangement the combined monthly payment consisting of membership dues in California Physicians' Service and contract payments to a hospital association are paid to one agency representing all four organizations. The agency then allocates to each organization the amount payable to it. In this manner an individual may secure both medical and hospital protection through one monthly payment. In such instances each member's medical and surgical benefits are evidenced by a certificate of beneficiary membership in California Physicians' Service and by a master medical service agreement with his group, while his hospitalization

(see note 8, supra) which includes dependents of municipal employecs, has appeared to prove this fact. "Unit" payments to physicians have been much less than "par" for several consecutive months, and we are informed that professional services to self-selected dependents has been a major factor in the forced reduction of the value of the unit.

${ }^{81}$ The hospital service corporations are: Insurance Association of Approved Hospitals, Associated Hos. pital Service of Southern California, and Intercoast Hospitalization Insurance Association.

${ }^{2}$ CAI. INs. CoDE, div. 2, pt. 2, c. I IA. See, also, discussion in note 17 , supra. 
benefits are evidenced by a hospitalization contract issued to him by one of the three hospital service corporations. The hospital service contracts of the hospital associations and the medical service agreements of California Physicians' Service have been prepared with this procedure in mind and accordingly the two supplement each other and avoid conflict or duplication in benefits offered.

Problem of Liability for Professional Torts (Malpractice): In California, actions against physicians for alleged negligence in diagnosis, treatment or care of a patient have become entirely too common ${ }^{53}$ to permit light treatment of the subject of physicians' liability or "malpractice" insurance in connection with any pooled-fund medical service plan.

Several possible liabilities had to be considered, namely, responsibility of each professional member for his own acts, responsibility of the Medical Director and his deputies and advisors for their acts in performing their duties as expressed in the rules and regulations, ${ }^{54}$ liability of California Physicians' Service, if any, for negligence of its professional members and its liability for negligence of its employees and agents including the Medical Director, his deputies and advisors.

The liability of professional members to beneficiary members for negligence in professional matters was met by (a) requiring all professional members to maintain in force professional liability insurance and (b) including an arbitration clause in all medical service agreements under which all claims and disputes between professional and beneficiary members must be submitted to arbitration by an independent arbitrator whose award- is final and binding. ${ }^{55}$ With respect to the Medical Director, deputy directors and advisors selected by California Physicians' Service, it is essential that complete insurance protection be maintained at all times covering each individual and California Physicians' Service for any liability that may be imposed upon it under the doctrine of respondeat superior.

Whether the funds of California Physicians' Service may be in jeopardy each time a service is performed by a professional member is an unanswered question. On principle it seems clear that, except for procedures performed or omitted under instructions of the Medical Director or one of his deputies, each professional member is acting independently so that he alone is responsible to his patient. However, to guard against a contrary opinion, the medical service agreements contain a clause expressly providing that California Physicians' Service is not answerable for the negligence of any professional member. ${ }^{58}$ In view of the fact that the funds of the

${ }^{53} \mathrm{~A}$ series of decisions applying the maxim res ipsa loqaitur in malpractice cases apparently stimulated malpractice litigation. Early in r939 the California Supreme Court reversed its trend and refused to apply res ipsa loquitur to a case involving severance of a nerve during surgery. Engelking v. Carlson, 97 Cal. Dec. 364,88 P. (2d) 695 (1939). $\quad$ See note 43, supra.

"In California, an arbitration clause is valid and specifically enforceable. Cas. Code Crv. Proc. \$\$1280-1286; Pacific Orient Co. v. Superior Court, 203 Cal. 797, 262 Pac. III7 (I928). Neither party can ignore the clause and maintain an action upon a matter which, under the clause, should have been arbitrated. Clogston v. Schiff-Lang Co., 2 Cal. (2d) 4I4, 4I P. (2d) 555 (1935); Note (I929) I7 CalIF. L. REv. 643 .

${ }^{\circ 0}$ The clause provides "C.P.S. acts only as agent of its professional members and assumes no liability for the breach of any one or all of the obligations undertaken by its professional members. In no case is C.P.S. an insurer against the negligence of its professional members. . .." 
Service may be said beneficially to belong to all beneficiary and professional members, so that their depletion to benefit one member would to that extent injure all others, there would appear to be no public policy contravened by the clause.

Two other precautions have been taken to protect California Physicians' Service. First, the arbitration clause previously mentioned, which should effectively discourage groundless actions filed for their nuisance value, and, second, insurance coverage.

Extension of Beneficiary Membership to Lowest Income Groups: Clearly, those persons now eligible to medical care at public expense ${ }^{57}$ are not concerned with a group prepayment medical care plan. There are also many persons with restricted incomes, either because of low wages or periodic intervals of enforced idleness, who may feel that they cannot afford health protection at their expense. It is possible that governmental subsidization of this group's medical costs (already accomplished in some communities) may become widespread.

If there is further extension of government subsidized medical care, some vehicle for rendering such service is necessary. For this reason the articles and by-laws of California Physicians' Service provide that the corporation has power to contract "for the performance of medical services by its professional members or for the furnishing of hospital care or both ... or for any other lawful object or purpose, with any public or municipal corporation, body politic, the State of California or any political subdivision of said State," or any administrative agency of the state or the United States of America, or "any corporation incorporated under the laws of the United States or any foreign state."

Under this power, California Physicians' Service is ready and able to undertake the same type of service that a number of non-profit corporations created by the Farm Security Administration render to needy farm groups and migrant workers. From the viewpoint of the taxpayer and the public it would seem unanswerable that an organization representing the entire medical profession is more likely to use public funds in an economical and efficient manner, subject, of course, to normal supervision, than any government agency untrained in the problems of the profession.

\section{Concruston}

We have endeavored to picture California Physicians' Service so that there may be an understanding of what it is and how it functions. If, as a consequence of this brief article, any light is cast upon the problem of payment for medical care that measures up to American standards and demands with respect to quality, then, its purpose has been more than fulfilled.

${ }^{67}$ In many California counties not only indigent residents but also residents with average incomes are, according to our information, admitted to the county hospital. These people are called "part-pay" patients, and generally are required to pay that portion of the county's cost for their care and attention that their resources or incomes warrant. 